\title{
Necrotizing placentitis in a cow caused by Bacillus cereus
}

\author{
Cláudia Emanuela Viana Rocha ${ }^{1}$ (D) João Paulo Leôncio Magalhães ${ }^{2}$ \\ Juliana Pinto da Silva $\mathrm{Mol}^{3}$ iD Andressa Cristine Borges Guedes ${ }^{3}$ \\ Erica Azevedo Costa ${ }^{4}$ (D) Henrique Cesar Pereira Figueiredo ${ }^{4}$ (D) \\ Renato de Lima Santos ${ }^{3}$ Tatiane Alves da Paixão ${ }^{{ }^{*}}$ (iD)
} ${ }^{1}$ Instituto de Ciências Biológicas, Universidade Federal de Minas Gerais (UFMG), 31270-901, Belo Horizonte, MG, Brasil. E-mail:
tatipaixao.ufmg@gmail.com "Corresponding author.
${ }^{2}$ Laboratório de Microbiologia - NOWAVET AGRO, Viçosa, MG, Brasil
${ }^{3}$ Departamento de Clínica e Cirurgia Veterinárias, Escola de Veterinária, Universidade Federal de Minas Gerais (UFMG), Belo Horizonte, MG, Brasil.
${ }^{4}$ Departamento de Medicina Veterinária Preventiva, Escola de Veterinária, Universidade Federal de Minas Gerais (UFMG), Belo Horizonte,
MG, Brasil.

ABSTRACT: This report described a case of necrotizing placentitis caused by Bacillus cereus in a cow associated with abortion and maternal lethality. The etiological diagnosis of placentitis by B. cereus was based on histopathology of placenta, cytology and bacterial isolation from intrauterine aminiotic fluid in retained placenta and further characterization of the pathogen by the MALDI-TOF. Although, B. cereus abortions are sporadic, the bacterium has the ability to release necrotizing toxins that can lead to placentitis, fetal death and abortion. Key words: Bacillus sp., placenta, infectious abortion, cattle.

Placentite necrotizante em uma vaca por Bacillus cereus

RESUMO: Este relato descreve a placentite necrotizante causada por Bacillus cereus em uma vaca associada a aborto e mortalidade materna. O diagnóstico etiológico de placentite por B. cereus foi baseado na histopatologia da placenta, citologia e isolamento bacteriano partir do líquido aminiótico em placenta retida e identificação do patógeno pela técnica de MALDI-TOF. Embora abortos por B. cereus sejam esporádicos, a bactéria tem a capacidade de liberar toxinas necrotizantes que podem levar a placentite e aborto.

Palavras-chave: Bacillus sp., placenta, aborto infeccioso, bovino.

Bacillus cereus is a Gram-positive aerobic or anaerobic facultative spore-forming rod bacterium. It is mobile and found in water, soil, plants and various sediments in the environment (BOTTONE, 2010). In cattle, B. cereus and B. licheniformis are two species considered opportunistic that are associated with mastitis (SCHIEFER et al., 1976; PARKINSON et al., 1999; MAVANGIRA et al., 2013) and abortion (SCHU \& WEINSTOCK, 1985; ANDERSON et al., 1990; KIRKBRIDE, 1993; AGERHOLM et al., 1997). Reports of bovine abortion caused by Bacillus spp. have been described in Europe (AGERHOLM et al., 1997; ODDSDOTTIR et al., 2004; DI BLASIO et al., 2019; WOLF-JÄCKEL et al., 2020), North America (ANDERSON et al., 1990; KIRKBRIDE, 1993; CLOTHIER \& ANDERSON, 2016), and
Oceania (REICHEL et al., 2018) with no previously reported cases in South America.

Necrotic, hemorrhagic and suppurated placentitis are often associated with Bacillus sp. infection. Bacillus sp.-induced fetal lesions include pneumonia, pericarditis, encephalitis, hepatitis, peritonitis, and inflammation of the thymus (LOGAN, 1988; KIRKBRIDE, 1993). Silage is considered an important source of contamination for cattle; although, Bacillus sp. is widely distributed in nature (LOGAN, 1988).

This report described for the first time in Brazil a bovine abortion in the final third of pregnancy caused by Bacillus cereus. A five-year-old Holstein cow, at 32 weeks of gestation, developed apathy, anorexia and pyrexia $\left(41.5{ }^{\circ} \mathrm{C}\right)$. During physical examination, the cow was not in labor and on rectal 
palpation the fetus was in an eutopic position with no movement. Antibiotic therapy (penicillin 10,000 IU/ $\mathrm{Kg}$ and gentamicin $160 \mathrm{mg} / \mathrm{kg}$ ) was administered every 48 hours in association with anti-inflammatory therapy (phenylbutazone OF 20\%, $12 \mathrm{~mL}$ ) daily. Twenty-four hours later, the cow presented external decubitus and fetal expulsion.

Male fetus with a crown-rump length of $57 \mathrm{~cm}$ was expelled with the fragments of the fetal membranes and a large amount of purulent, fetid and bloody fluid. A few hours after fetal expulsion, clinical condition of the cow worsened, progressing to death. Blood samples from the cow were collected for hemogram, and samples of the aminiotic fluid from the intrauterine retained placenta were collected for cytology and bacterial isolation. At necropsy, the cow presented an accumulation of fibrinopurulent necrotizing exudate covering the caruncles within the uterus and fetal membranes thickened with pyosanguinolent exudate. Fragments of the placentome were collected for histopathological examination. Necropsy examination of the stillborn was not performed.

The cow had leukocytosis with left deviation. The cytological examination of the aminiotic fluid in the panotic stained smears revealed numerous red blood cells and degenerate neutrophils, some of which with high numbers of elongated bacillary microbial structures often sporulated. Gram stained smears demonstrated numerous Grampositive elongated rods with central endospore, compatible with microorganisms of the genus Bacillus both extracellular or within the cytoplasm of macrophages (Figure 1A).

Samples of the placentome were referred to the pathology service at the Veterinary School of

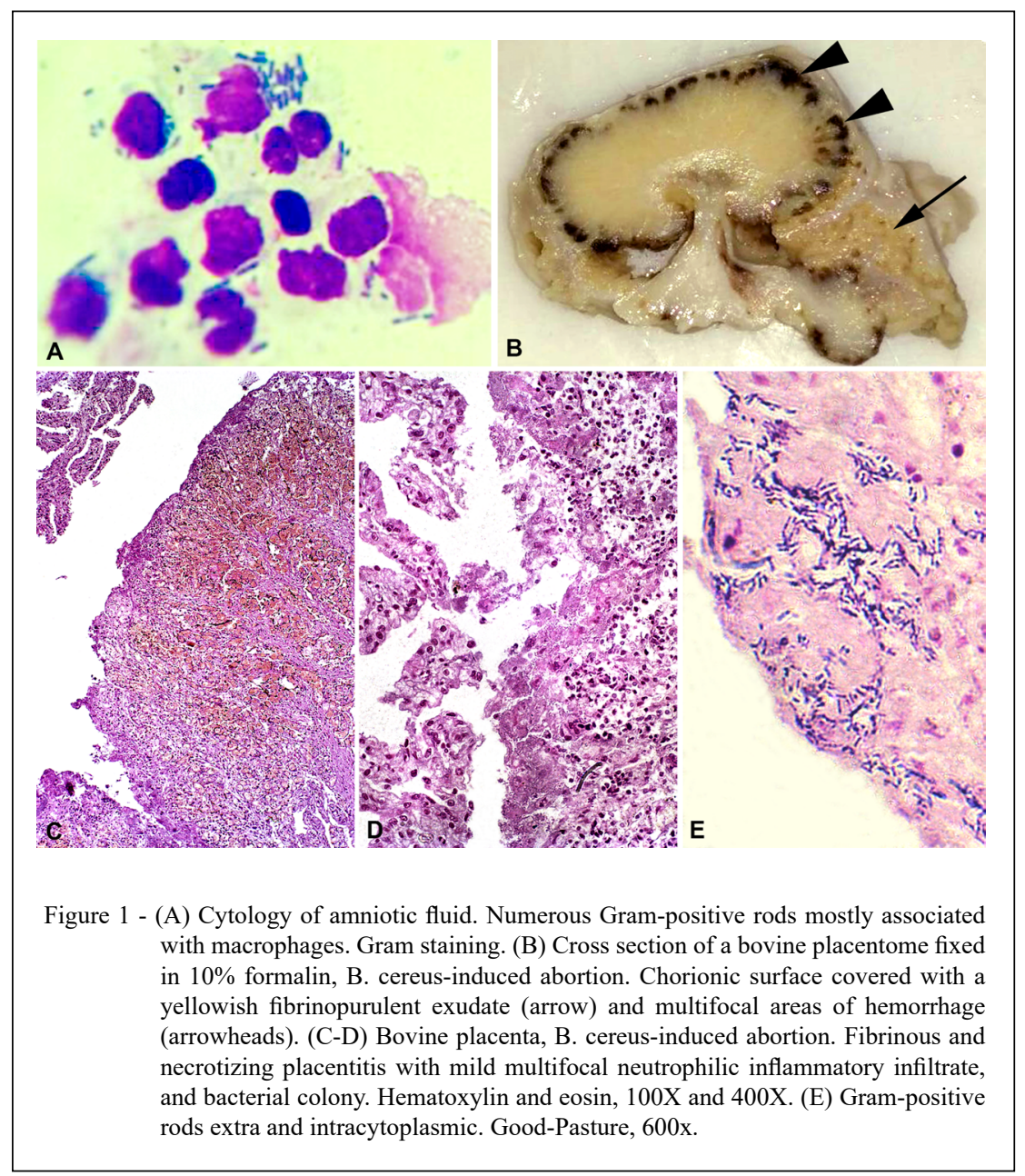

Ciência Rural, v.51, n.6, 2021. 
the Universidade Federal de Minas Gerais (UFMG, Belo Horizonte, Brazil). Grossly, cross sections of fixed fragments of placenta had multifocal to coalescing hemorrhage, particularly at the arcade region (caruncular surface and bases of the chorionic villi), and accumulation of fibrinopurulent exudate (Figure 1B).

Microscopically, there was a moderate multifocal neutrophilic inflammatory infiltrate in the placenta with necrosis, accumulation of fibrin, and myriad of Gram-positive bacterial colonies, in the form of rods, with both extracellular and intracellular localization in trophoblastic cells. Macrophages containing brown pigments were observed with multifocal distribution. Morphological diagnosis of fibrinonecrotizing placentitis with intralesional Grampositive bacteria was established (Figure 1C-E).

The etiological diagnosis of placentitis by B. cereus was confirmed by bacterial isolation, which included aerobic and anaerobic protocols. Bacteria were isolated when $5 \mathrm{~mL}$ of the aminiotic fluid was heated at $62{ }^{\circ} \mathrm{C}$ for 15 minutes, subsequently, plated on sheep blood $5 \%$ agar, and incubated at $37^{\circ} \mathrm{C}$ for 24-48 hours. Beta hemolytic, irregular, large and matte colonies were submitted to biochemical tests in order to identify the microbial species. The isolates were motility + , catalase + , oxidase-, urease-, citrate + , gelatin+, nitrates reduction+, voges proskauer+, lecithinase + , esculin hydrolysis + . Results were validated according to the taxonomic key of the ABIS ONLINE software (https://www.tgw1916. net/bacteria_logare.html) with an accuracy of $99 \%$. Additionally, when the isolates were cultured in serum agar and incubated with $10 \% \mathrm{CO}_{2}$ there was formation of capsule. Cultures in brain heart infusion broth were sent to the Aquacen laboratory (UFMG Veterinary School), where the bacterium was identified as $B$. cereus by the MALDI-TOF (Matrix Associated Laser Desorption-Ionization - Time of Flight) mass spectrometry as previously described (ASSIS et al., 2017).

In addition, other important pathogens associated with bovine abortion or placentitis were investigated by PCR with DNA templates extracted from formalin-fixed placental samples. DNA extraction was performed according to SILVA et al., 2009 and PCR reactions performed as previously described for Brucella sp. Leptospira sp., Neospora caninum (SILVA et al., 2009), Listeria monocytogenes (BUBERT et al., 1999), and Herpesvirus Bovine Type 1 (VAN ENGELENBURG, et al., 1993). The quality of the extracted DNA was confirmed by the positive PCR reaction for amplification of the bovine $\alpha$ - actin gene (SILVA et al., 2009). Negative and positive controls were included in each reaction. The etiological diagnosis of placentitis by $B$. cereus in this case was confirmed by bacterial isolation from aminiotic fluid collected directly from the uterine cavity and specific identification by a comprehensive biochemical panel and MALDI-TOF mass spectrometry. Fibrinopurulent placentitis was the probable cause of the clinical changes presented by the cow, which were associated with abortion followed by maternal death.

The cow in this report was approximately at eight months of pregnancy with clinical signs of pyrexia, apathy and anorexia, and absence of fetal movement. Therefore, in this case, fetal death preceded fetal expulsion as reported in previously described cases (SCHUH \& WEINSTOCK, 1985). $B$. cereus-induced abortion followed by death of the cow has not been previously described; although, cases of gangrenous mastitis due to $B$. cereus infection are often lethal due to toxemia (SCHIEFER et al., 1976).

In cases of abortion in domestic animals caused by Bacillus spp. that the pathogen may be isolated from vaginal swabs, placenta, fetal abomasal contents, heart, liver, lung, bronchial and mediastinum lymph nodes of aborted fetuses (LOGAN et al., 1988). In this case, B. cereus was isolated from aminiotic fluid while fetal membranes were still within the uterus, which minimized environmental contamination.

JOHNSON et al. (1994) considered placentome a good tissue to obtain the definitive etiological diagnosis because it allows associating isolation with necrotic placentitis lesion, which may allow a conclusive diagnosis even without access to fetal tissues. There is evidence of abortion with necrotic placentitis by $B$. cereus without fetal injury, even if there is bacterial colonization in the fetus (SCHUH \& WEINSTOCK, 1985). In this report, the fetus was not available and the only tissue sent for hispathological examination was a placentome, which along with microbiological examination of the aminiotic fluid supported a conclusive diagnosis of necrotic placentitis with intralesional Gram-positive bacteria (Bacillus cereus).

Considering that $B$. cereus is an ubiquitous microorganism, isolation of the bacteria by itself is not sufficient for a conclusive diagnosis since the isolated bacterium may be an environmental contaminant. The diagnosis of bovine abortion by $B$. cereus is usually based on the pure culture of the microorganism isolated from placenta and/or fetus, with presence of microorganisms within microscopic lesions, and the absence of other agents known to cause abortion in cattle (SCHUH \& WEINSTOCK, 1985). In 
this case, no other infectious agent was isolated on microbiological examination or detected by PCR. Furthermore, the visualization of phagocytosed Gram-positive bacteria by macrophages present in the amniotic fluid indicates that this agent was not an environmental contaminant, but it was present within the uterus prior to fetal expulsion and it was associated with the intrauterine inflammatory reaction.

The pathogenesis of $B$. cereus-induced abortion is unknown; although, $B$. cereus secretes several enzymatic or lytic exotoxins, including phospholipases, hemolysins, pore-forming enterotoxins, and cytotoxin K (LOGAN, 1988, BOTTONE, 2010). According to SCHUH \& WEINSTOCK (1985), one of the consequences of toxins produced by $B$. cereus is a necrotizing placentitis followed by death and fetal expulsion before fetal injury or even colonization of fetal tissues by B. cereus (SCHUH \& WEINSTOCK, 1985). Studies suggested that bovine abortions caused by $B$. cereus may be associated to virus-induced immunosuppression as occurs in cases of bovine viral diarrheavirusinfection(SCHUH\&WEINSTOCK,1985; KIRKBRIDE, 1993). In conclusion; although, it is an opportunistic agent, B. cereus should be considered in the differential diagnosis of sporadic infectious bovine abortion in the country.

\section{ACKNOWLEDGMENTS}

This work has financial support of Fundação de Amparo à Pesquisa do Estado de Minas Gerais (FAPEMIG), Conselho Nacional de Desenvolvimento Científico e Tecnológico (CNPq) and Coordenação de Aperfeiçoamento de Pessoal de Nível Superior (CAPES), Brasil - Finance code 001. CEVR are supported by CAPES and HCPF, RLS and TAP are supported by CNPq.

\section{BIOETHICS AND BIOSSECURITY COMMITTEE APPROVAL}

We authors of the article entitled "Necrotizing placentitis in a cow caused by Bacillus cereus" declared, for all due purposes, the project that gave rise to the present data of the same has not been submitted for evaluation to Ethics Committee of the Universidade Federal de Minas Gerais", but we are aware of the content of the Brazilian resolutions of the National Council for Control of Animal Experimentation - CONCEA "http://www.mct.gov.br/index.php/content/view/310553.html" if it involves animals.

Thus, the authors assume full responsibility for the presented data and are available for possible questions, should they be required by the competent authorities.

\section{DECLARATION OF CONFLICTS OF INTERESTS}

The authors declare no conflict of interest. The founding sponsors had no role in the design of the study; in the collection, analyses, or interpretation of data; in the writing of the manuscript, and in the decision to publish the results.

\section{AUTHORS' CONTRIBUTIONS}

CEVR, RLS and TAP worked in conception and writing of the manuscript. CEVR, JPLM, JPSM, ACBG, EAC, HCPF carried out the lab analyses. All authors critically revised the manuscript and approved of the final version.

\section{REFERENCES}

AGERHOLM, J. S. et al. Diagnostic studies of abortion in Danish dairy herds. Journal of Veterinary Medicine Series A, v.44, n. 1-10, p.551-558, 1997. Available from: <https://onlinelibrary.wiley.com/ doi/abs/10.1111/j.1439-0442.1997.tb01141.x>. Accessed: May, 25, 2020. doi: 10.1111/j.1439-0442.1997.tb01141.x.

ANDERSON, M. L. et al. A survey of causes of bovine abortion occurring in the San Joaquin Valley, California. Journal of Veterinary Diagnostic Investigation, v.2, n.4, p.283-287, 1990. Available from: <https://journals.sagepub.com/doi/10. 1177/104063879000200405>. Accessed: May, 25, 2020. doi: $10.1177 / 104063879000200405$.

ASSIS, G. B. N. et al. Use of MALDI-TOF mass spectrometry for the fast identification of gram-positive fish pathogens. Frontiers in Microbiology, v.8, p.1-12, 2017. Available from: <https:// www.frontiersin.org/articles/10.3389/fmicb.2017.01492/full>. Accessed: May, 25, 2020. doi: 10.3389/fmicb.2017.01492.

BOTTONE, E. J. Bacillus cereus, a volatile human pathogen. Clinical Microbiology Reviews, v.23, n.2, p.382-398, 2010. Available from: <https://cmr.asm.org/content/cmr/23/2/382.full. pdf>. Accessed: May, 25, 2020. doi: 10.1128/CMR.00073-09.

BUBERT, A. et al. Detection and differentiation of Listeria spp. by a single reaction based on multiplex PCR. Applied and Environmental Microbiology, v.65, n.10, p.4688-4692, 1999. Available from: $<$ https://aem.asm.org/content/aem/65/10/4688.full.pdf $>$. Accessed: Oct. 30, 2020. doi: 10.1128/AEM.65.10.4688-4692.1999.

CLOTHIER, K.; ANDERSON, M. Evaluation of bovine abortion cases and tissue suitability for identification of infectious agents in California diagnostic laboratory cases from 2007 to 2012. Theriogenology, v.85, n.5, p.933-938, 2016. Available from: $\quad<$ https://www.sciencedirect.com/science/article/abs/pii/ S0093691X1500610X?via\%3Dihub>. Accessed: May, 25, 2020. doi: 10.1016/j.theriogenology.2015.11.001.

DI BLASIO, A. et al. Isolation of Arcobacter species and other neglected opportunistic agents from aborted bovine and caprine fetuses. BMC Veterinary Research, v.15, n.1, p.257, 2019. Available from: <https://bmcvetres.biomedcentral.com/ articles/10.1186/s12917-019-2009-3>. Accessed: May, 25, 2020. doi: 10.1186/s12917-019-2009-3.

JOHNSON, C. T.; et al. The bovine placentome in bacterial and mycotic abortions. The Veterinary record, v.134, n.11, p.263266, 1994. Available from: <https:/veterinaryrecord.bmj.com/ content/134/11/263>. Accessed: May, 25, 2020. doi: 10.1136/ vr.134.11.263.

KIRKBRIDE, C. A. Bacterial agents detected in a lo-year study of bovine abortions and stillbirths. Journal of Veterinary Diagnostic 
Investigation, v.5, n.1, p.64-68, 1993. Available from: <https:// journals.sagepub.com/doi/pdf/10.1177/104063879300500114>. Accessed: May, 25, 2020. doi: 10.1177/104063879300500114.

LOGAN, N. A. Bacillus species of medical and veterinary importance. Journal of medical microbiology, v.25, n.3, p.157 165, 1988. Available from: < https://www.microbiologyresearch. org/content/journal/jmm/10.1099/00222615-25-3-157>. Accessed: May, 25, 2020. doi: 10.1099/00222615-25-3-157.

MAVANGIRA, V. et al. Gangrenous mastitis caused by Bacillus species in six goats. Journal of the American Veterinary Medical Association, v.242, n.6, p.836-843, 2013. Available from: <https:// avmajournals.avma.org/doi/abs/10.2460/javma.242.6.836>. Accessed: May, 25, 2020. doi: 10.2460/javma.242.6.836.

ODDSDOTTIR, C. et al. Preliminary diagnostic survey on causes of prenatal mortality in Icelandic cattle. Acta Veterinaria Scandinavica (print Edition), v.45, n.3-4, p.225-228, 2004 Available from: <https:/actavetscand.biomedcentral.com/ articles/10.1007/BF03449136>. Accessed: May, 25, 2020. doi: 10.1007/BF03449136.

PARKINSON, T. J. et al. A case of bovine mastitis caused by Bacillus cereus. New Zealand Veterinary Journal, v.47, n.4, p.151-152, 1999. Available from: <https://www.tandfonline.com/ doi/abs/10.1080/00480169.1999.36134>. Accessed: May, 25, 2020. doi: 10.1080/00480169.1999.36134.

REICHEL, M. P. et al. Review of diagnostic procedures and approaches to infectious causes of reproductive failures of cattle in Australia and New Zealand. Frontiers in Veterinary Science v.5, p.222, 2018. Available from: <https://www.frontiersin.org/ articles/10.3389/fvets.2018.00222/full>. Accessed: May, 25, 2020. doi: $0.3389 /$ fvets. 2018.00222

SCHIEFER, B. et al. Pathology of Bacillus cereus mastitis in dairy cows. The Canadian Veterinary Journal, v.17, n.9, p.239-243, 1976. Available from: <https://www.ncbi.nlm.nih.gov/pmc/ articles/PMC1697321/pdf/canvetj00394-0029.pdf>. Accessed: May, 25, 2020

SCHUH, J.; WEINSTOCK, D. Bovine abortion caused by Bacillus cereus. Journal of the American Veterinary Medical Association, v.187, n.10, p.1047-1048, 1985.

SILVA, T. M. A., et al. Etiologic diagnosis of bovine infections abortion by PCR. Ciência Rural, v.39, n.9, p.2563-2570, 2009. Available from: <https://www.scielo.br/pdf/cr/v39n9/ a401cr1871.pdf $>$. Accessed: Oct. 30, 2020. doi: 10.1590/S010384782009000900028

VAN ENGELENBURG, F. A. C.; et al. Development of a rapid and sensitive polymerase chain reaction of bovine herpesvirus type 1 in bovine semen. Journal of Clinical Microbiology, v.31, p.31293135, 1993. Available from: < https://www.ncbi.nlm.nih.gov/pmc/ articles/PMC266363/pdf/jcm00024-0065.pdf $>$. Accessed: Oct. 30, 2020 .

WOLF-JÄCKEL, G. A. et al. Diagnostic studies of abortion in Danish cattle 2015-2017. Acta Veterinaria Scandinavica, v.62, n.1, p.1, 2020. Available from: <https://actavetscand. biomedcentral.com/articles/10.1186/s13028-019-0499-4>. Accessed: May, 25, 2020. doi: 10.1186/s13028-019-0499-4. 